\title{
Synergistic effects of a novel lipid-soluble extract from Pinellia pedatisecta Schott and cisplatin on human cervical carcinoma cell lines through the regulation of DNA damage response signaling pathway
}

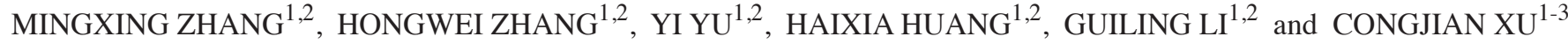 \\ ${ }^{1}$ Department of Integration of Western and Traditional Medicine, Obstetrics and Gynecology Hospital; \\ ${ }^{2}$ Shanghai Key Laboratory of Female Reproductive Endocrine Related Diseases, Fudan University, \\ Shanghai 200011; ${ }^{3}$ Institute of Biomedical Sciences, Fudan University, Shanghai 200032, P.R. China
}

Received January 23, 2016; Accepted December 6, 2016

DOI: $10.3892 / \mathrm{ol} .2017 .5738$

\begin{abstract}
Herbal medicines have been recognized as an attractive approach for cancer therapy with minimal side effects. The present study investigated the type of interaction between a novel lipid-soluble extract from Pinellia pedatisecta Schott (PE) and cisplatin (CDDP) on human cervical cancer $\mathrm{SiHa}$ and CaSki cell lines in vitro. The mechanism of this combination was studied using cell proliferation, invasion and apoptosis assays, and by analyzing cell cycle distribution and protein expression, with a focus on DNA damage response (DDR) activation. Equipotent combinations of PE and CDDP were determined by isobologram analysis, in order to evaluate potential synergy. The combination index for SiHa cells was 0.43 , and the index for CaSki cells was 0.68 , indicating synergy. Treatment with PE and CDDP combined resulted in a significantly greater inhibition of invasion in the two cells, compared with either drug alone ( $\mathrm{SiHa}, \mathrm{P}<0.01$; CaSki, $\mathrm{P}<0.001)$. This co-treatment induced significantly more apoptosis in the two cell lines, and arrested cells at the G0/G1 phase and G2/M phase in SiHa and CaSki, respectively, with a significant decrease $(\mathrm{P}<0.01)$ in $\mathrm{S}$ phase cells in the two cell lines. Combined PE and CDDP targeting synergistically enhanced the expression of markers of DDR (phosphorylation of ataxia-telangiectasia mutated, checkpoint kinase (Chk)-1, Chk-2, and $\gamma-\mathrm{H} 2 \mathrm{~A}$ histone family member X) in cells. These results suggest that $\mathrm{PE}$ and cisplatin act synergistically in
\end{abstract}

Correspondence to: Professor Guiling Li or Professor Congjian Xu, Shanghai Key Laboratory of Female Reproductive Endocrine Related Diseases, Fudan University, 419 Fangxie Road, Shanghai 200011, P.R. China

E-mail: guilingli@fudan.edu.cn

E-mail: xucongjian@gmail.com

Key words: Pinellia pedatisecta Schott, PE, cisplatin, cervical carcinoma, synergistic cervical cancer cells with high DDR activation. The approach presented in the present study may have important implications for the pharmacological mechanism of Pinellia pedatisecta Schott and cervical cancer therapeutic strategies.

\section{Introduction}

Cervical cancer is one of the most prevalent malignancies among women, particularly in developing countries, with $\sim 527,600$ new cases and $\sim 265,700$ mortalities in 2012 worldwide (1). In addition, the age-standardized incidence of cervical cancer has been $>4$ per 100,000 (1998-2002) in China (2), with age-standardized 5-year (2005-09) net survival of $\sim 60 \%(3,4)$. It therefore remains a challenge for the Chinese government to prevent this disease. Although the first-line treatment for early stages of cervical cancer is surgical excision, concomitant platinum-based chemoradiotherapy remains a curative treatment for local advanced cervical cancer, particularly for distant control of the disease $(5,6)$.

As one of the first-line chemotherapeutic agents in the treatment of cervical cancer, cis-dichlorodiamine platinum-II, also termed cisplatin (CDDP), exerts its cytotoxic effect predominantly by formatting an intra-strand cross-linking on DNA that blocks transcription and DNA replication, resulting in DNA damage response (DDR) $(7,8)$. However, the chemotherapeutic use of CDDP is limited by its severe side effects and drug resistance $(9,10)$. Combining CDDP with new anti-cancer agents has been studied to improve this clinical dilemma. Such combined treatments enable a lower cytotoxic dose of CDDP without affecting the therapeutic benefits. The purpose of the present study was to investigate a novel lipid-soluble extract (PE) from Pinellia pedatisecta Schott, which is a traditional Chinese medicine (TCM).

The research on Pedate pinellia Rhizome can be traced back to the 1970s, when 247 cases of cervical cancer were treated, and the total effective rate was $81.5 \%$ (11). The present study was focused on PE, which was extracted by the Shanghai Institute of Materia Medica, Chinese Academy of Sciences. Unlike Western medicine, which generally uses purified 
compounds and aims to target a single molecule, TCM compositions usually contain multiple herbs and components that are necessary for efficacy $(12,13)$. Initial studies identified the key constituents of the lipid-soluble extract as alkaloids, fatty acids and $\beta$-sitosterol $(11,14)$. However, the key constituents are not necessarily efficacious or therapeutic for cervical cancer. Limited by TCM ingredient analytical technology, study of the exact curative component is progressing slowly in the Shanghai Institute of Materia Medica, Chinese Academy of Sciences. Previous studies have evaluated the cytotoxic effect of PE on cervical cancer cell lines (15). The present study identified that PE could synergistically enhance the cytotoxicity of CDDP against CaSki cell growth in xenograft tumors in vivo. However, little is known about the effect of this combination on the malignant biological behavior of cervical cell lines and the underlying mechanisms. The present study aimed to assess the synergistic effect of PE when combined with CDDP on human cervical cancer cell lines in vitro and the potential mechanism on the DDR pathway.

\section{Materials and methods}

Reagents. Dried rhizomes of Pinellia pedatisecta Schott were purchased from Xuchang Pharmaceutical Corporation (Henan, China) in June 2013, and authenticated by Professor Jin-gui Shen of the Shanghai Institute of Materia Medica, Chinese Academy of Sciences. The extracting technique and process of PE have been described in detail in a previous study (15). A voucher specimen was deposited in the herbarium of the Shanghai Institute of Materia Medica. PE was stored in a freezer at $-80^{\circ} \mathrm{C}$. The $\mathrm{PE}$ was then dissolved in dimethyl sulfoxide at a concentration of $500 \mu \mathrm{g} / \mu \mathrm{l}$, and stored at $4^{\circ} \mathrm{C}$ for a week prior to use. CDDP was purchased from Sigma-Aldrich (Merck Millipore, Darmstadt, Germany). Rabbit monoclonal antibodies directed against cleaved-PARP (dilution, 1:1,000; \#9185), cleaved-caspase-3 (dilution, 1:1,000; \#9664), phosphorylated ataxia-telangiectasia mutated (ATM; Ser1918; dilution, 1:1,000; \#5883) phosphorylated-checkpoint kinase (Chk)-1 (Ser345) (dilution, 1:1,000; \#2348), phosphorylated-Chk-2 (Ser68) (dilution, 1:1,000; \#2197) and -H2A histone family member X (H2AX) (Ser139) (dilution, 1:1,000; \#9718) were purchased from Cell Signaling Technology, Inc. (Danvers, MA, USA). The anti-GAPDH antibody (dilution, 1:5,000; \#9482) was obtained from Abcam (Cambridge, MA, USA). The Cell Counting Kit-8 (CCK-8) was purchased from Dojindo Molecular Technologies, Inc. (Kumamoto, Japan) and the AlexaFluor 488 Annexin V/Dead Cell Apoptosis kit was obtained from Invitrogen (Thermo Fisher Scientific, Inc., Waltham, MA, USA).

Cell culture. The human cervical cancer cell lines SiHa and CaSki were obtained from the American Type Culture Collection (Manassas, VA, USA) and resuscitated by the Cell Bank of the Chinese Academy of Science (Shanghai, China). SiHa and CaSki cells were routinely cultured in minimum essential medium and RPMI-1640 medium, respectively, with $10 \%$ fetal bovine serum (FBS; Gibco; Thermo Fisher Scientific, Inc.), $100 \mathrm{IU} / \mathrm{ml}$ penicillin $\mathrm{G}$, and $100 \mathrm{mg} / \mathrm{ml}$ streptomycin sulfate (Sigma-Aldrich; Merck Millipore). The incubation conditions were $37^{\circ} \mathrm{C}$ under $5 \% \mathrm{CO}_{2}$ and $95 \%$ air atmosphere at constant humidity. The culture medium was changed every other day.
Cell proliferation assay and isobologram analysis. To obtain the appropriate concentration of PE and CDDP in the following experiment, the half-maximal inhibitory concentration (IC50) was determined in the CaSki and SiHa cell lines. CaSki cells cultured in 96-well plates were treated with various concentrations of PE $(0,100,200,400$ and $800 \mu \mathrm{g} / \mathrm{ml})$, or CDDP $(0,1.25,2.5,5,10,20,40,60$ and $80 \mu \mathrm{g} / \mathrm{ml})$ for 24,48 and $72 \mathrm{~h}$. $\mathrm{SiHa}$ cells cultured in 96-well plates were treated with various concentrations of PE $(0,100,200,400,800$ and 1,600 $\mu \mathrm{g} / \mathrm{ml})$ or CDDP $(0,1.25,2.5,5,10,20,40$ and $60 \mu \mathrm{g} / \mathrm{ml})$ for the same time periods. CCK-8 assay was performed to investigate the cytotoxicity of PE and CDDP on CaSki and SiHa, following treatment for different time periods. Cell viability percentage was determined relative to the control. Each experiment was performed in 6 replicate wells for each drug concentration. Cell growth curves were drawn and the IC50 values at $48 \mathrm{~h}$ were calculated with CalcuSyn software analysis (Version 2.1; Biosoft, Cambridge, UK).

CaSki and SiHa cells were seeded onto 96-well plates at a cell density of 50,000 cells per well in $100 \mu \mathrm{l}$ cell culture medium, $24 \mathrm{~h}$ prior to being treated with different doses of $\mathrm{PE}, \mathrm{CDDP}$ or a combination of the two. For the SiHa cells, six concentrations of PE $(15.6,31.2,62.5,125,250$ and $500 \mu \mathrm{g} / \mathrm{ml})$ and CDDP $(2.5,5,10,20,40$ and $80 \mu \mathrm{g} / \mathrm{ml})$ were assayed. However, for the CaSki cells, five concentrations of PE $(15.6,31.2,62.5,125$ and $250 \mu \mathrm{g} / \mathrm{ml})$ and CDDP $(2.5,5,10$, 20 and $40 \mu \mathrm{g} / \mathrm{ml}$ ) were assayed. The relation ratio between the mixtures was 6:1. After treatment for $48 \mathrm{~h}$, the cell culture medium was replaced with $100 \mu \mathrm{l}$ fresh medium containing $10 \mu \mathrm{l} \mathrm{CCK}-8$ solution and incubation continued at $37^{\circ} \mathrm{C}$ for $2 \mathrm{~h}$. The absorbance was then measured at $450 \mathrm{~nm}$ using the Multiskan MK3 (Thermo Fisher Scientific, Inc.). The percentage of cell proliferation was determined relative to the control. Each experiment was performed in six replicate wells for each drug concentration.

Interactions between PE and CDDP were evaluated by the isobologram analysis method, which was applied to determine additive, synergistic and antagonistic effects (16).

Cell invasion assay and cell anti-proliferation assay. Cell invasion assays were conducted with $8 \mu \mathrm{m}$ hanging cell culture inserts (Millipore Filter Corporation; Merck Millipore, Bedford, MA, USA) with polycarbonate membrane. Each insert was coated with $80 \mu \mathrm{l}$ of Matrigel (BD Biosciences, San Jose, CA, USA), followed by incubation at $37^{\circ} \mathrm{C}$ for $4 \mathrm{~h}$. Cells were trypsinized and adjusted to $2 \times 10^{5}$ cells $/ \mathrm{ml}$ in serum-free medium with PE $(125 \mu \mathrm{g} / \mathrm{ml}$ for CaSki and $250 \mu \mathrm{g} / \mathrm{ml}$ for $\mathrm{SiHa}), \mathrm{CDDP}(20 \mu \mathrm{g} / \mathrm{ml}$ for CaSki and $40 \mu \mathrm{g} / \mathrm{ml}$ for $\mathrm{SiHa})$, or a combination of the two. Cells $(500 \mu \mathrm{l})$ were seeded in the upper chambers of 24 -well plates, and $600 \mu \mathrm{l}$ of $10 \%$ FBS medium was added to the bottom of the chamber and incubated for $48 \mathrm{~h}$ in the invasion assay. The cells were then fixed with $4 \%$ paraformaldehyde for $10 \mathrm{~min}$ at room temperature and the Matrigel was wiped off the upper surface. The cells were then stained with $0.5 \%$ crystal violet solution for $5 \mathrm{~min}$ prior to rinsing with PBS. The number of migratory cells was counted in 3 random fields for each group using a light microscope (magnification, x100) and presented as a percentage compared with the control. For each treatment, three repetitions were performed. 
Assessment of apoptosis and cell cycle distribution. Apoptosis was detected by flow cytometry via the examination of altered plasma membrane phospholipid packing, using the lipophilic dye Annexin V. Cells were treated with PE, CDDP or a combination of the two, as aforementioned in the cell invasion assay, and harvested for $48 \mathrm{~h}$ after treatment. The cells were successively washed with cold PBS and binding buffer, and were subsequently re-suspended in binding buffer at a concentration of $1 \times 10^{6} \mathrm{cells} / \mathrm{ml}$. Thereafter, $5 \mu \mathrm{l}$ of Annexin V-FITC and $1 \mu \mathrm{l}$ of propidium iodide (PI) were added to $200 \mu$ l of cell suspension and incubated for $15 \mathrm{~min}$ at room temperature, avoiding light. Following the addition of $300 \mu \mathrm{l}$ of binding buffer, the labeled cells were immediately counted by flow cytometry. All early apoptotic cells (Annexin V-positive, propidium iodide-negative), necrotic/late apoptotic cells (double positive) and living cells (double negative) were detected using a FACSCalibur flow cytometer (BD Biosciences) and subsequently analyzed by FlowJo software 7.6.1 (BD Biosciences).

For cell cycle analyses, treated cells were fixed in $75 \%$ ethanol for $24 \mathrm{~h}$, at $-20^{\circ} \mathrm{C}$. Following centrifugation at $352 \mathrm{x} g$ for 5 min at $4^{\circ} \mathrm{C}$, the cells were collected and re-suspended in PBS (400 $\mu \mathrm{l})$, RNase A $(10 \mathrm{mg} / \mathrm{ml}, 50 \mu \mathrm{l})$, and PI $(2 \mathrm{mg} / \mathrm{ml}, 10 \mu \mathrm{l})$. The mixtures were incubated in the dark at $37^{\circ} \mathrm{C}$ for $30 \mathrm{~min}$ prior to flow cytometric analysis by a Beckman Coulter CyAn ADP flow cytometer (Beckman Coulter, Inc., Brea, CA, USA).

Western blot analysis. Treated cells from a 60-mm dish were lysed in $50 \mu \mathrm{l}$ radioimmunoprecipitation assay buffer (50 mM Tris- $\mathrm{HCl}, \mathrm{pH} 7.4 ; 150 \mathrm{mM} \mathrm{NaCl} ; 1 \% \mathrm{NP} 40 ; 0.25 \%$ Na-deoxycholate; $1 \mathrm{mM}$ EDTA; $1 \mathrm{mM}$ phenylmethane sulfonyl fluoride; and protease inhibitor cocktail). Following 15 min of centrifugation $\left(2880 \mathrm{x} g\right.$ at $\left.4^{\circ} \mathrm{C}\right)$, the supernatant was collected and the concentration of total protein was measured using a Bio-Rad (Bio-Rad Laboratories, Inc., Hercules, CA, USA) protein assay kit. An aliquot of $30 \mu \mathrm{g}$ total protein was resolved in a $10 \%$ sodium dodecyl sulfate polyacrylamide gel and transferred to a polyvinylidene membrane. The membrane was blocked in 5\% nonfat milk in PBS with Tween-20 (PBST; $20 \mathrm{mM}$ Tris- $\mathrm{HCl} ; 150 \mathrm{mM} \mathrm{NaCl} ; 0.05 \%$ Tween-20) at room temperature for $60 \mathrm{~min}$. The membranes were then incubated with the aforementioned primary antibodies overnight at $4^{\circ} \mathrm{C}$. The membrane was then washed 3 times with PBST and incubated with horseradish peroxidase-conjugated goat anti-rabbit secondary antibody (\#7170S; Cell Signaling Technology, Inc.) at a 1:10,000 dilution for $1 \mathrm{~h}$ at room temperature. The membranes were then washed 3 times for $60 \mathrm{~min}$. The specific protein bands were visualized using electrochemiluminescence western blotting substrate (Pierce; Thermo Fisher Scientific, Inc.) and imaged using ImageQuant ${ }^{\mathrm{TM}}$ LAS4000 (GE Healthcare Life Sciences, Chalfont, UK). Protein levels were normalized to GAPDH as a reference.

Statistical analysis. For isobologram analysis, CalcuSyn 2.1 was used, and the combination index values $<1,=1$ and $>1$ were used to indicate synergy, additivity and antagonism, respectively. Statistical analysis of the data was performed using either GraphPad Prism 6 software (GraphPad Software, La Jolla, CA, USA) or SPSS 16.0 (SPSS, Inc., Chicago, IL, USA). Data were expressed as the mean \pm standard deviation of three independent experiments. Differences among groups were analyzed statistically with one-way analysis of variance, followed by the Bonferroni post hoc test for multiple comparisons. A unpaired two-tailed Student's t-test was applied to identify significant differences between two groups. $\mathrm{P}<0.05$ was considered to indicate a statistically significant difference.

\section{Results}

Synergistic interaction between $P E$ and $C D D P$. Subsequent to treatment with different concentrations of PE and CDDP for $72 \mathrm{~h}$, cell growth curves were drawn. As shown in Fig. 1, cytotoxicity of PE and CDDP was in a time and dose-dependent manner on CaSki and SiHa cell lines. IC50 at $48 \mathrm{~h}$ was calculated by CalcuSyn software. For CaSki cells, the IC50 of CDDP was $40 \mu \mathrm{g} / \mathrm{ml}$ and that of PE was $250 \mu \mathrm{g} / \mathrm{ml}$, while for SiHa cells, the IC50 of CDDP was $80 \mu \mathrm{g} / \mathrm{ml}$ and that of PE was $500 \mu \mathrm{g} / \mathrm{ml}$.

The inhibitory effects of the combined use of PE and CDDP were tested in two cervical cancer cell lines, SiHa and CaSki cells. To determine whether PE and CDDP exhibit a combined effect in cervical cancer cells, the effect of individual and combination treatment with $\mathrm{PE}$ and CDDP after $48 \mathrm{~h}$ of exposure was examined, using the CCK-8 assay. As shown in Fig. 2A, the two compounds inhibited cell growth in a dose-dependent manner in $\mathrm{SiHa}$ and CaSki cells. Isobologram analysis was performed to evaluate whether PE and CDDP interact synergistically (Fig. 2B). This analysis provides a combination index $(\mathrm{CI})$ value that measures the degree of interaction between two or more drugs, where a $\mathrm{CI}<1$ indicates synergism and CI $>1$ antagonism. CI values of 0.43 and 0.68 were identified for $\mathrm{SiHa}$ and $\mathrm{CaSki}$ cells when the effective dose (ED) of the two agents inhibited cell viability by $50 \%$ (Fig. 2C). Irrespective of high cytotoxicity (ED90) or low cytotoxicity (ED25), the CI value remained below 1, indicating that synergism occurs independently of the equipotency levels of PE and CDDP. Results of the present study demonstrate that PE and CDDP exhibit a synergistic interaction in cervical cancer cell lines.

Combination of CDDP with PE inhibits cervical cancer cell invasion. To test whether the combination of PE plus CDDP results in decreased cell invasion compared with either single agent alone, Matrigel invasion chambers were used. Results in Fig. 3 show that, for SiHa and CaSki cell lines, PE alone caused $\sim 63$ and $49 \%$ reduction in invasion compared with the control, while the combination treatment decreased cell invasion by $\sim 88$ and $81 \%$, respectively.

Combination of CDDP with PE increases cervical cancer cell apoptosis and G0/G1 or G2/M phase arrest. To determine whether the increased anti-proliferative effect was due to increased apoptosis and/or cell cycle alterations, apoptosis was examined using Annexin $\mathrm{V}$ analysis, following PE and CDDP treatment (Fig. 4). The number of apoptotic cells was quantified using flow cytometry (Fig. 4A and B). As shown in Fig. 4C and D, flow cytometric analysis of SiHa and CaSki cells revealed that $\mathrm{PE}$ and CDDP increased the number of apoptotic cells compared with that observed in untreated cells. Additionally, the combined targeting significantly enhanced $\mathrm{SiHa}$ and CaSki cell apoptosis to 86.8 and $48.4 \%$, respectively. These results were confirmed by western blot analysis. The 
CaSki

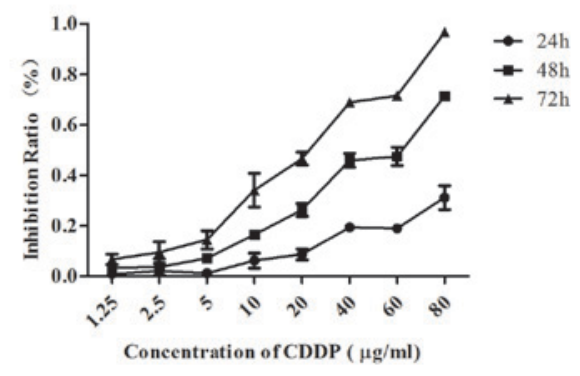

CaSki

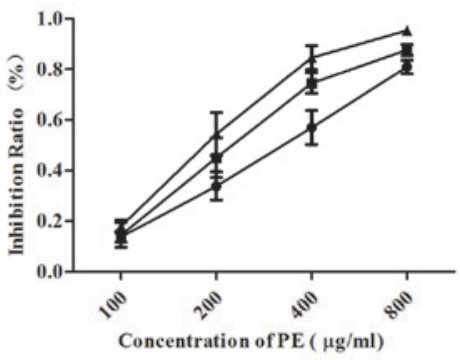

$\mathrm{SiHa}$

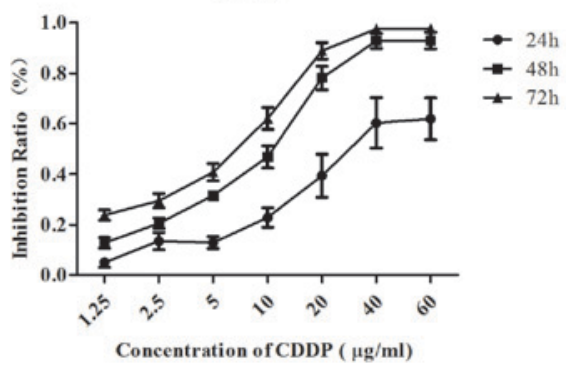

$\mathrm{SiHa}$

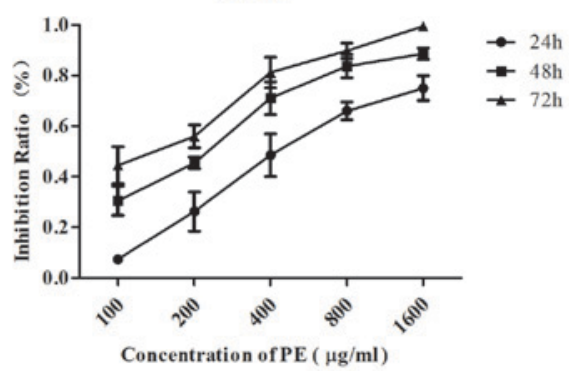

Figure 1. Cell growth curves following treatment with PE or CDDP for 24, 48 and 72 h. CDDP, cisplatin; PE, lipid-soluble extract from Pinellia pedatisecta.

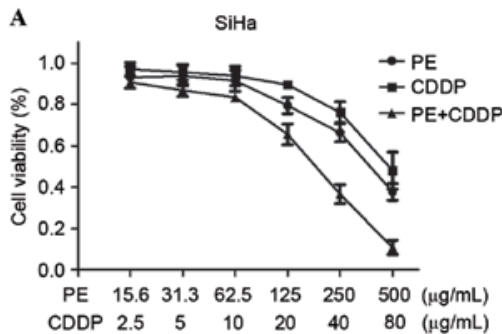

B
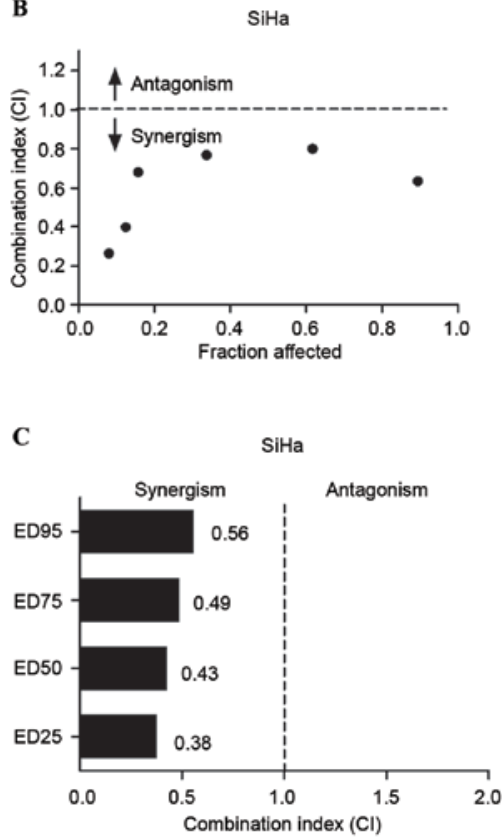

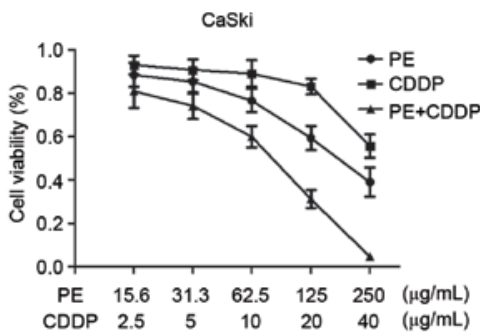

Caski
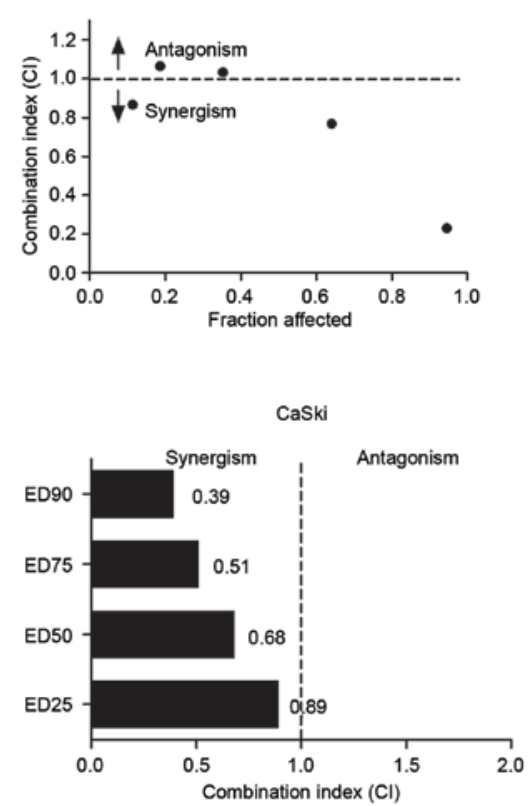

Figure 2. PE and CDDP exhibit synergistic cytotoxicity in SiHa and CaSki cells. (A) Cell viability was measured by the Cell Counting Kit-8 assay. SiHa and CaSki cells were treated with the indicated concentrations of PE and CDDP for $48 \mathrm{~h}$. (B) Isobologram analysis of combination treatment with PE and CDDP in $\mathrm{SiHa}$ and CaSki cells. The line designates the $\mathrm{CI}$, where $\mathrm{CI}=1$ (additive effect), $\mathrm{CI}<1$ indicates synergism and $\mathrm{CI}>1$ represents antagonism. (C) The $\mathrm{CI}$ values for a combination of PE and CDDP at a range of ED. The CI at ED25, ED50, ED75 and ED90 indicate a synergistic interaction between PE and CDDP in SiHa and CaSki cells. CDDP, cisplatin; CI, combination index; ED, effective dose; PE, lipid-soluble extract from Pinellia pedatisecta Schott. 
A

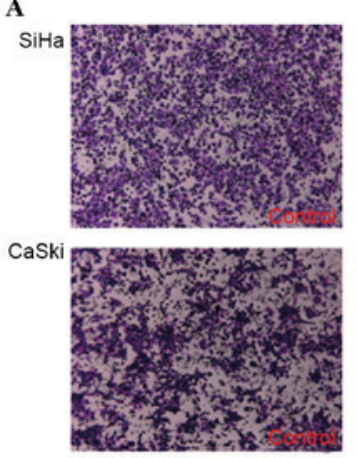

B

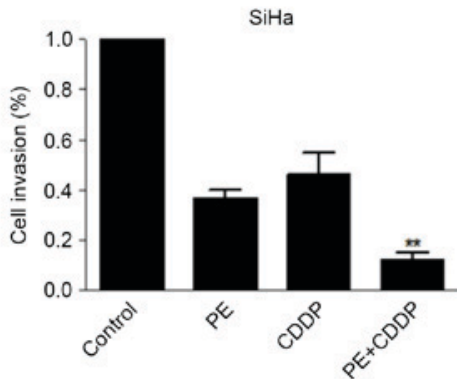

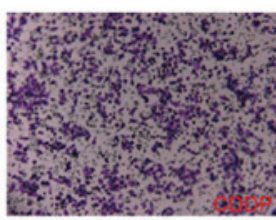
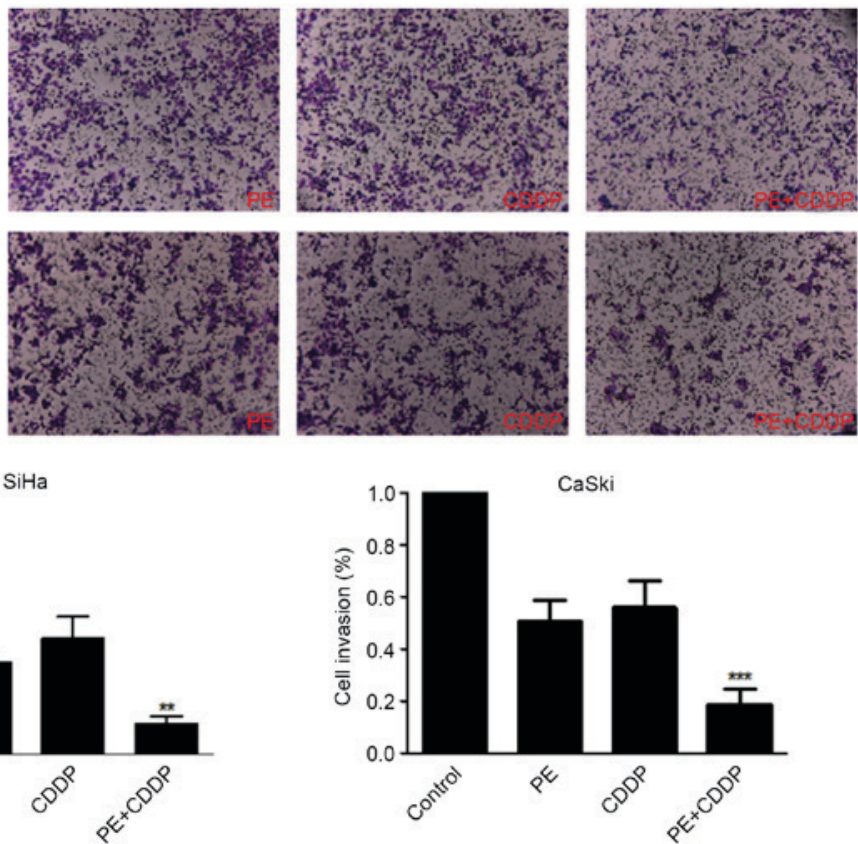

Figure 3. Combination of PE with CDDP decreases cell invasion in SiHa and CaSki cell lines. Cells were treated with PE, CDDP, and their combination. (A) Cells were plated on Matrigel invasion chambers and invading cells were counted using light microscopy (magnification, x100). Columns represent the means of three identical wells of a single representative experiment. Bars represent the upper $95 \%$ confidence interval; ${ }^{* * *} \mathrm{P}<0.05$ and ${ }^{* * * *} \mathrm{P}<0.001$, for comparisons between cells treated with the combined treatment and cells treated with CDDP. CDDP, cisplatin; PE, lipid-soluble extract from Pinellia pedatisecta Schott.

SiHa

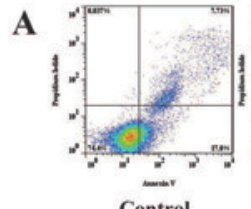

C

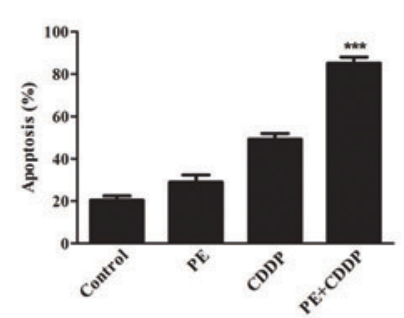

E

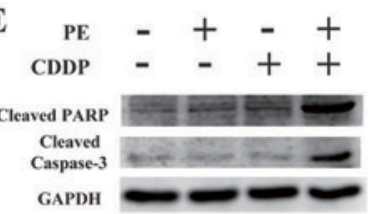

\section{CaSki}

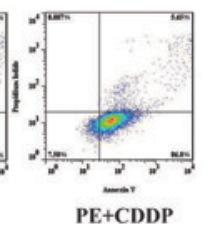

B
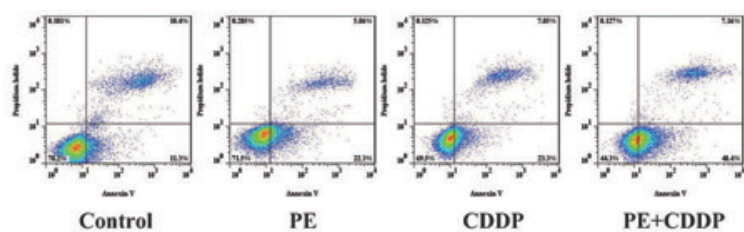

D

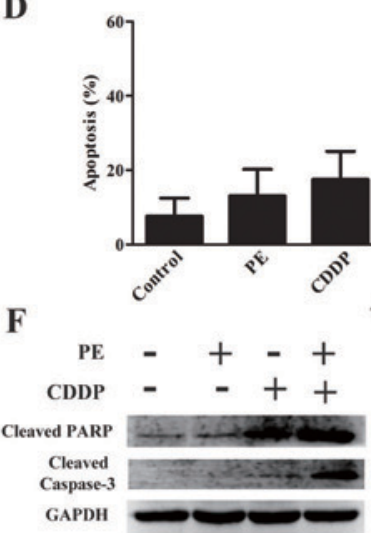

Figure 4. Effects of PE and/or CDDP on apoptosis in SiHa and CaSki cell lines. Apoptosis was evaluated as aforementioned with Annexin V staining in SiHa and CaSki cells; the cells were treated with PE, CDDP, and their combination. (A and B) Representative dot plots illustrating the data near the mean of the groups. (C and D) Columns, means of 3 identical wells of a single representative experiment; bars, upper $95 \%$ confidence interval; ${ }^{* * * *} \mathrm{P}<0.001$ for comparisons between cells treated with the combined treatment and cells treated with CDDP. (E and F) Western blot analysis of PARP and caspase-3 cleavage following treatments with PE alone or with CDDP. CDDP, cisplatin; PE, lipid-soluble extract from Pinellia pedatisecta Schott; PARP, poly ADP-ribose polymerase.

combination of PE with CDDP was accompanied by increased expression of cleaved PARP and caspase-3 (Fig. 4E and F). As shown in Fig. 5, a significant increase $(\mathrm{P}<0.001)$ in $\mathrm{G} 2 / \mathrm{M}$-phase cells following treatment with CDDP plus PE was observed compared with the single treatment in CaSki cells. For $\mathrm{SiHa}$ cells, a significant increase $(\mathrm{P}<0.01)$ in $\mathrm{G} 0 / \mathrm{G} 1$-phase cells was observed. This cell cycle delay was also accompanied by a decreased percentage of S-phase cells.

Combination of PE with CDDP enhances activation of the DNA damage response. To further understand how PE and CDDP function to inhibit tumor cell growth synergistically, 

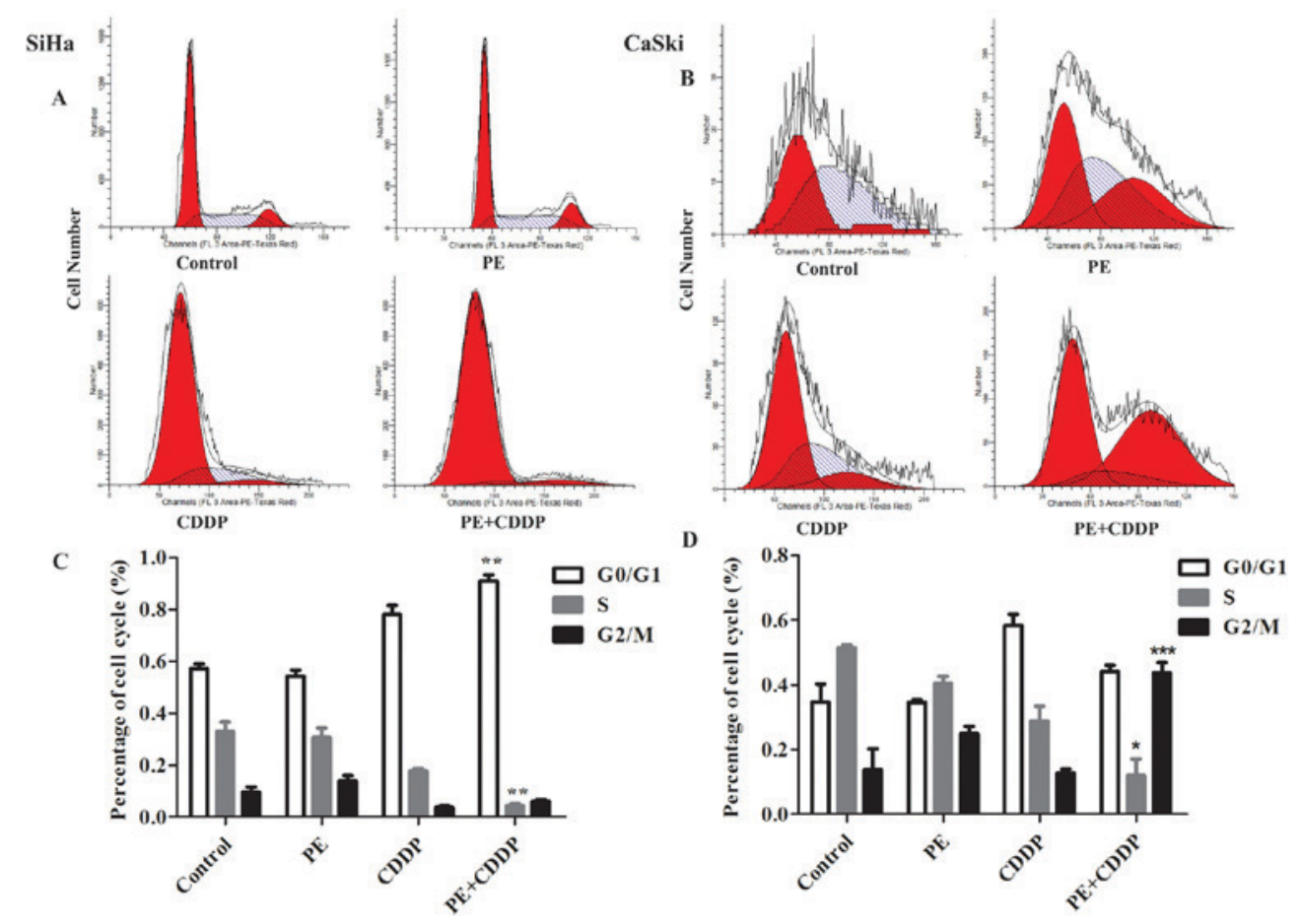

Figure 5. Effect of PE and/or CDDP on the cell cycle in SiHa and CaSki cell lines. The cell cycle was assessed as aforementioned with propidium iodide and RNase staining of SiHa and CaSki cells; the cells were treated with PE $(250 \mu \mathrm{g} / \mathrm{ml}$ or $125 \mu \mathrm{g} / \mathrm{ml})$, CCDP $(40 \mu \mathrm{g} / \mathrm{ml}$ or $20 \mu \mathrm{g} / \mathrm{ml})$, and their combination. (A and B) Representative dot plots illustrating the data near the mean of the groups. (C and D) Columns, means of 3 identical wells of a single representative experiment; ${ }^{*} \mathrm{P}<0.05,{ }^{* *} \mathrm{P}<0.01$ and ${ }^{* * * *} \mathrm{P}<0.001$ for comparisons between cells treated with the combined treatment and cells treated with CDDP. CDDP, cisplatin; PE, lipid-soluble extract from Pinellia pedatisecta.

the phosphorylation state of crucial components of the DDR pathway was assessed in the cells, following treatment with different doses of PE, CDDP or a combination of the two. Western blot analyses were performed on proteins from $\mathrm{SiHa}$ cells treated with $40 \mu \mathrm{g} / \mathrm{ml}$ of CDDP, $250 \mu \mathrm{g} / \mathrm{ml}$ of PE, or a combination of the two, and the treatment was conducted for $48 \mathrm{~h}$. Proteins from CaSki cells that were treated with $20 \mu \mathrm{g} / \mathrm{ml}$ of CDDP, $125 \mu \mathrm{g} / \mathrm{ml}$ of PE, or a combination of the two for $48 \mathrm{~h}$ were detected in the same way. As shown in Fig. 6, when co-treated with PE and CDDP, the two cell lines manifested increased phosphorylation of ATM, Chk-1, Chk-2 and H2AX compared with single agent treatment.

\section{Discussion}

TCM, which has been used in China for thousands of years, has a unique theoretical system and takes a practical approach to the treatment of diseases (17). The 'Shen Nong Ben Cao Jing', written $>2,000$ years ago, was one of the earliest books on medicine in the world $(17,18)$. The effectiveness of TCM against cancer is an area of investigation among oncologists and clinicians. There are multiple anti-cancer studies on various TCMs, including berberine (19), chrysin (20), jacarelhyperol A (21) and curcuma longa $(22,23)$. Furthermore, evidence suggests that TCMs possess synergistic effects when combined with common chemotherapeutic drugs, enhancing toxicity against cancer cells and prolonging survival time $(24,25)$. These combinations could also decrease the side effects of chemotherapeutic drugs and improve the quality of life in patients $(26,27)$.

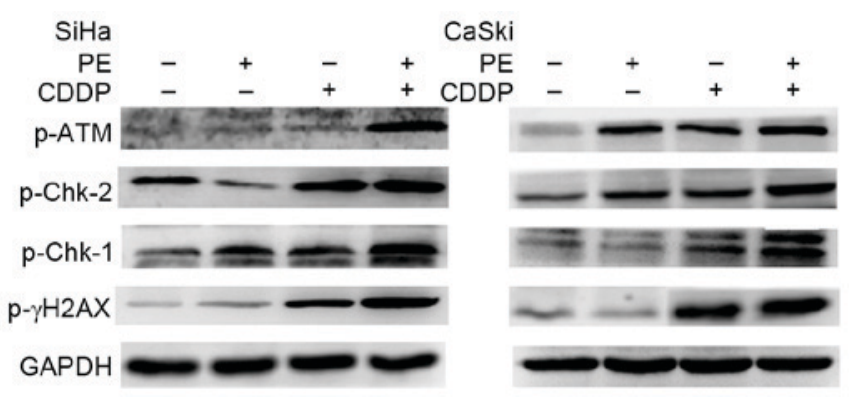

Figure 6. Effects on DNA damage reaction pathways following treatment with $\mathrm{PE}$ and CDDP in SiHa and CaSki cells. Proteins from cells treated with the indicated concentrations of $\mathrm{PE}$ and CDDP for $48 \mathrm{~h}$ were detected by western blotting of phosphorylation of ATM, Chk-1, Chk-2 and $\gamma$-H2AX. GAPDH was used to normalize protein levels. CDDP, cisplatin; PE, lipid-soluble extract from Pinellia pedatisecta Schott; $\mathrm{p}$-Chk, phosphorylated checkpoint kinase; p-ATM, phosphorylated ataxia-telangiectasia mutated; $\gamma$-H2A, $\gamma$-H2AX, histone family member X.

Pinellia pedatisecta rhizome has long been used as a TCM to treat Thanatophidia bites, nameless swelling, toxicum and cancer. It was recorded to exhibit efficacy at dispelling wind, relieving convulsions, drying dampness to eliminate phlegm, and eliminating stagnation (28). Previous studies have focused on Pinellia pedatisecta agglutinin, which has potential value in immunotherapy against drug-resistant cancer cells through inducing the tumoricidal activity of macrophages (29) and distinguishing among glycosylation patterns in various cancer cell lines (30). Total protein of Pinellia pedatisecta Schott has 
been reported to inhibit the growth of SKOV3 cells and lead to proteomic changes in the SKOV3 cell strain (31). A novel lipid-soluble extract (PE) from Pinellia pedatisecta has been investigated by the present authors for 10 years (Zhang et al, unpublished data). A previous in vivo study demonstrated that PE had a synergistic cytotoxic effect on CaSki cell growth in xenograft tumors in vivo, when combined with CDDP. This led to the investigation of whether $\mathrm{PE}$ has a synergistic effect when combined with CDDP on cervical cancer cell lines in vitro.

In the present study, $\mathrm{PE}$ and CDDP were shown individually to cause inhibition of cell growth in $\mathrm{SiHa}$ and CaSki cells in a dose-dependent manner. To extend analysis of the synergistic interactions between PE and CDDP, different concentrations of PE and CDDP were used to treat cervical cell lines. Drug $\mathrm{CI}$ analysis was used to evaluate the interactions between two drugs for a long time period. The median-effect method was created by Chou and Talalay, and $\mathrm{CI}<1,=1$ and $>1$ indicate synergy, additivity and antagonism, respectively (16). Cell viability assays in the present study determined the $\mathrm{CI}$, at quality ratios of 6:1 (PE: CDDP), for SiHa cells to be 0.43 , and that for CaSki cells was 0.68. This provides evidence of the synergistic anti-proliferative effect. The synergistic effect of the combination treatment on cell apoptosis, cell cycle and cell invasion was then examined in the two cell lines. As shown in Fig. 3, although PE or CDDP alone decreased cervical cancer cell invasion, combined targeting significantly enhanced the effect compared with either treatment alone. Cells were arrested in G0/G1 or G2/M-phase in SiHa and CaSki cells, respectively, with a significant decrease $(\mathrm{P}<0.01)$ in $\mathrm{S}$-phase cells. Similarly, combination of PE with CDDP strongly and synergistically induced apoptosis in the two cell lines (Fig. 4). The activation of caspase- 3 and PARP was observed in the two cell lines treated with PE and CDDP. Caspase-3 and PARP protein serve a key role in the execution-phase of cell apoptosis $(32,33)$. Results show that the combined use of PE and CDDP synergistically inhibited cervical cancer progression. However, the mechanisms responsible for the synergistic effects of using PE and CDDP are not understood.

It is known that the efficacy of platinum-based chemotherapy is dependent on the generation of DNA damage and the subsequent induction of apoptosis (34). DNA has been a main target of cancer therapy, since DNA damage could initiate a cascade of events that ultimately determines the fate of cancer cells (35). A DDR induced by a chemotherapeutic drug can lead to permanent cell cycle arrest or apoptosis, thus avoiding the proliferation or survival of premalignant clones (36). Modulation of the DDR network may alter the response of cancer cells to DNA damaging anticancer drugs, including CDDP and doxorubicin (37,38). This endogenous DDR involves the activation of DNA damage sensors (including ATM) and the activation of the cell cycle checkpoint kinases Chk-1 and Chk-2 together with the phosphorylation of the histone H2AX (39). To investigate the potential mechanism of the synergistic effect of PE and CDDP, western blot analysis of the primary protein in the DDR pathway was conducted. As shown in Fig. 6, the phosphorylation levels of ATM and $\gamma$-H2AX were increased more by treatment with PE plus CDDP than by either treatment alone. Therefore, the potential mechanism is possibly associated with enhancing the activation of the ATM/pChk-2 pathway to induce p53-mediated cell apoptosis in cervical cancer cells in vitro.
This phenomenon has also been observed in other TCMs. Wang et al (40) identified that curcumin could sensitize budding yeast to DNA damage by counteracting the DDR. Berberine was reported to be able to induce apoptosis and DNA damage in MG-63 cells (41). A number of studies have observed that herbal extracts are able to protect normal cells from DNA damage caused by certain unfavorable factors. It was stated that Ginkgo biloba extract (EGb 761), an antioxidant herbal medicine, can notably alleviate endothelial DNA oxidation caused by intermittent high glucose in human umbilical vein endothelial cells (42). In addition, Citri reticulatae Pericarpium can effectively protect against hydroxyl-induced DNA damage by donating a hydrogen atom/electron (43). Furthermore, the TCM compound rocaglamide protects nonmalignant primary cells from DNA damage-induced toxicity by inhibition of p53 expression, but this protective effect was not in malignant tumor cells with defective or mutant p53 (44). In the present study, it was observed that PE can induce DNA damage in cervical cancer cells, and thereby cause cell apoptosis, and it can also enhance the DDR caused by CDDP. Nevertheless, whether PE can protect normal cells from DNA damage caused by CDDP, as well as the upstream molecular reaction ATM/pChk-2 pathway in this process remains unclear and further investigation is necessary.

The present data and previous findings indicate that $\mathrm{PE}$ and CDDP inhibit the growth of cervical cancer cell lines synergistically. The potential mechanism may be associated with enhancing the DDR pathway to induce apoptotic signals in cervical cancer cells in vitro. The presented approach may have important implications for the pharmacological mechanism of Pinellia pedatisecta and therapeutic strategies for cervical cancer.

\section{Acknowledgements}

The present study was supported by National Natural Sciences Foundation of China (grant no. 81373867) awarded to Guiling Li.

\section{References}

1. Torre LA, Bray F, Siegel RL, Ferlay J, Lortet-Tieulent J and Jemal A: Global cancer statistics, 2012. CA Cancer J Clin 65: 87-108, 2015.

2. Shi JF, Canfell K, Lew JB and Qiao YL: The burden of cervical cancer in China: Synthesis of the evidence. Int J Cancer 130: 641-652, 2012.

3. Allemani C, Weir HK, Carreira H, Harewood R, Spika D, Wang XS, Bannon F, Ahn JV, Johnson CJ, Bonaventure A, et al: Global surveillance of cancer survival 1995-2009: Analysis of individual data for $25,676,887$ patients from 279 population-based registries in 67 countries (CONCORD-2). Lancet 385: 977-1010, 2015.

4. Ferlay J, Forman D, Mathers CD and Bray F: Breast and cervical cancer in 187 countries between 1980 and 2010. Lancet 379: 1390-1391, 2012.

5. Jelavić TB, Miše BP, Strikic A, Ban M and Vrdoljak E: Adjuvant chemotherapy in locally advanced cervical cancer after treatment with concomitant chemoradiotherapy-room for improvement? Anticancer Res 35: 4161-4165, 2015.

6. Penson RT, Huang HQ, Wenzel LB, Monk BJ, Stockman S, Long HJ III, Ramondetta LM, Landrum LM, Oaknin A, Reid TJ, et al: Bevacizumab for advanced cervical cancer: Patient-reported outcomes of a randomised, phase 3 trial (NRG Oncology-Gynecologic Oncology Group protocol 240). Lancet Oncol 16: 301-311, 2015. 
7. Jamieson ER and Lippard SJ: Structure, recognition, and processing of cisplatin-dna adducts. Chem Rev 99: 2467-2498, 1999.

8. Chaney SG, Campbell SL, Bassett E and Wu Y: Recognition and processing of cisplatin- and oxaliplatin-DNA adducts. Crit Rev Oncol Hematol 53: 3-11, 2005.

9. Sprowl JA, Lancaster CS, Pabla N, Hermann E, Kosloske AM, Gibson AA, Li L, Zeeh D, Schlatter E, Janke LJ, et al: Cisplatin-induced renal injury is independently mediated by OCT2 and p53. Clin Cancer Res 20: 4026-4035, 2014.

10. Karasawa T and Steyger PS: An integrated view of cisplatin-induced nephrotoxicity and ototoxicity. Toxicol Lett 237 219-227, 2015.

11. Li CJ, Xu YM and Sun YL: Research on anti-cervical cancer component of Pinellia pedatisecta Schott. J Shanghai Med Univ 8: 421-423, 1981 (In Chinese).

12. Poornima P, Kumar JD, Zhao Q, Blunder M and Efferth T: Network pharmacology of cancer: From understanding of complex interactomes to the design of multi-target specific therapeutics from nature. Pharmacol Res 111: 290-302, 2016.

13. Duan Y, Pei K, Cai H, Tu S, Cheng X, Zhang Z, Fan K, Qiao F, Qin K and Cai B: Strategy of integrated evaluation on treatment of traditional Chinese medicine as 'interaction of system to system' and establishment of novel fuzzy target contribution recognition with herb-pairs, a case study on Astragali Radix-FructusCorni. Mol Cell Endocrinol 434: 219-237, 2016.

14. Chemistry Department of Basic Research Center, Obstetrics and Gynecology Hospital: Research of Pinellia pedatisecta Schott on cervical cancer. Shanghai Medical Journal 1: 13-16, 1978 (In Chinese).

15. Li GL, Jiang W, Xia Q, Chen SH, Ge XR, Gui SQ and Xu CJ: HPV E6 down-regulation and apoptosis induction of human cervical cancer cells by a novel lipid-soluble extract (PE) from Pinellia pedatisecta Schott in vitro. J Ethnopharmacol 132: 56-64, 2010.

16. Chou TC and Talalay P: Quantitative analysis of dose-effect relationships: The combined effects of multiple drugs or enzyme inhibitors. Adv Enzyme Reguln 22: 27-55, 1984.

17. Ding $\mathrm{H}$ and Wang Z: Experience of treatment and understanding of impediment disease in Shen nong ben cao jing (Shen-ntonz's Classic of Materia Medica). Zhonghua Yi Shi Za Zhi 45: 3-6, 2015 (In Chinese).

18. Endo J, Nakamura T, Yamaki H and Miyamoto H: Studies of the fifth section in the introduction of the Qian jin yao fang-Writings quoted from the Shen nong ben cao jing and the Yao dui. Yakushigaku Zasshi 28: 1-5, 1993 (In Japanese).

19. Liu X, Ji Q, Ye N, Sui H, Zhou L, Zhu H, Fan Z, Cai J and Li Q: Berberine inhibits invasion and metastasis of colorectal cancer cells via COX-2/PGE2 mediated JAK2/STAT3 signaling pathway. PLoS One 10: e0123478, 2015.

20. Kasala ER, Bodduluru LN, Madana RM, V AK, Gogoi R and Barua CC: Chemopreventive and therapeutic potential of chrysin in cancer: Mechanistic perspectives. Toxicol Lett 233: 214-225, 2015.

21. Zhang J, Li S, An FF, Liu J, Jin S, Zhang JC, Wang PC, Zhang X, Lee CS and Liang XJ: Self-carried curcumin nanoparticles for in vitro and in vivo cancer therapy with real-time monitoring of drug release. Nanoscale 7: 13503-13510, 2015.

22. Devassy JG, Nwachukwu ID and Jones PJ: Curcumin and cancer: Barriers to obtaining a health claim. Nutr Rev 73: 155-165, 2015

23. Zhang S, Yin J, Li X, Zhang J, Yue R, Diao Y, Li H, Wang H, Shan L and Zhang W: Jacarelhyperol A induced apoptosis in leukaemia cancer cell through inhibition the activity of Bcl-2 proteins. BMC Cancer 14: 689, 2014.

24. Chen Q, Qin R, Fang Y and Li H: Berberine sensitizes human ovarian cancer cells to cisplatin through miR-93/PTEN/Akt signaling pathway. Cell Physiol Biochem 36: 956-965, 2015.

25. Gao X, Wang B, Wu Q, Wei X, Zheng F, Men K, Shi H, Huang N, Wei $\mathrm{Y}$ and Gong C: Combined delivery and anti-cancer activity of paclitaxel and curcumin using polymeric micelles. J Biomed Nanotechnol 11: 578-589, 2015.
26. Xu L, Wang S, Zhuang L, Lin J, Chen H, Zhu X, Bei W, Zhao Q, Wu H and Meng Z: Jian Pi Li Qi Decoction alleviated postembolization syndrome following transcatheter arterial chemoembolization for hepatocellular carcinoma: A randomized, double-blind, placebo-controlled trial. Integr Cancer Therpii 15: 349-357, 2016.

27. Jaladat AM, Atarzadeh F, Rezaeizadeh H, Mofid B, Mosalaie A, Farhan F and Amin G: Botanicals: An alternative remedy to radiotherapy-induced dysuria. Complement Ther Med 23: 90-99, 2015.

28. He Y, L WL and Wang X: Pharmacological study of the rhizome powder of Pinellia pedatisecta processed by different procedures. Zhong Yao Cai 20: 459-461, 1997 (In Chinese).

29. Chen K, Yang X, Wu L, Yu M, Li X, Li N, Wang S and Li G: Pinellia pedatisecta agglutinin targets drug resistant K562/ADR leukemia cells through binding with sarcolemmal membrane associated protein and enhancing macrophage phagocytosis. PLoS One 8: e74363, 2013.

30. Li N, Dong G, Wang S, Zhu S, Shen Y and Li G: Pinellia pedatisecta agglutinin-based lectin blot analysis distinguishes between glycosylation patterns in various cancer cell lines. Oncol Lett 8: 837-840, 2014.

31. Chen XY, Zhou L and Zheng FY: Proteomic study of total protein of Pinellia pedatisecta Schott effect on human ovarian cancer SKOV3 cells. Zhongguo Zhong Xi Yi Jie He Za Zhi 31: 1651-1656, 2011 (In Chinese)

32. Tangutoori S, Baldwin P and Sridhar S: PARP inhibitors: A new era of targeted therapy. Maturitas 81: 5-9, 2015.

33. Porter AG and Jänicke RU: Emerging roles of caspase-3 in apoptosis. Cell Death Differ 6: 99-104, 1999.

34. Galluzzi L, Vitale I, Michels J, Brenner C, Szabadkai G, Harel-Bellan A, Castedo M and Kroemer G: Systems biology of cisplatin resistance: Past, present and future. Cell Death Dis 5: e1257, 2014.

35. Hurley LH: DNA and its associated processes as targets for cancer therapy. Nat Rev Cancer 2: 188-200, 2002.

36. Kastan MB and Bartek J: Cell-cycle checkpoints and cancer. Nature 432: 316-323, 2004.

37. Dungl DA, Maginn EN and Stronach EA: Preventing damage limitation: Targeting DNA-PKcs and DNA double-strand break repair pathways for ovarian cancer therapy. Front Oncol 5: 240, 2015.

38. El-Awady RA, Semreen MH, Saber-Ayad MM, Cyprian F, Menon V and Al-Tel TH: Modulation of DNA damage response and induction of apoptosis mediates synergism between doxorubicin and a new imidazopyridine derivative in breast and lung cancer cells. DNA Repair (Amst) 37: 1-11, 2015.

39. O'Connor MJ: Targeting the DNA Damage Response in cancer. Mol Cell 60: 547-560, 2015

40. Wang SH, Lin PY, Chiu YC, Huang JS, Kuo YT, Wu JC and Chen CC: Curcumin-mediated HDAC inhibition suppresses the DNA Damage Response and contributes to increased DNA Damage sensitivity. PLoS One 10: e0134110, 2015

41. Zhu Y, Ma N, Li HX, Tian L, Ba YF and Hao B: Berberine induces apoptosis and DNA damage in MG63 human osteosarcoma cells. Mol Med Rep 10: 1734-1738, 2014.

42. He YT, Xing SS, Gao L, Wang J, Xing QC and Zhang W: Ginkgo biloba attenuates oxidative DNA damage of human umbilical vein endothelial cells induced by intermittent high glucose. Pharmazie 69: 203-207, 2014

43. Li X, Huang YP and Chen DF: Protective effect against hydroxyl-induced DNA damage and antioxidant activity of citri reticulatae pericarpium. Adv Pharm Bull 3: 175-181, 2013.

44. Becker MS, Schmezer P, Breuer R, Haas SF, Essers MA, Krammer PH and Li-Weber M: The traditional Chinese medical compound Rocaglamide protects nonmalignant primary cells from DNA damage-induced toxicity by inhibition of $\mathrm{p} 53$ expression. Cell Death Dis 5: e1000, 2014. 